\title{
Prostate Cancer Clinical Regional Lymph Nodes TNM Finding v7
}

National Cancer Institute

\section{Source}

National Cancer Institute. Prostate Cancer Clinical Regional Lymph Nodes TNM Finding v7. NCl Thesaurus. Code C89222.

A clinical finding about one or more characteristics of prostate cancer, following the rules of the TNM AJCC V7 classification system as they pertain to staging of regional lymph nodes. (from AJCC 7th Ed.) 